\title{
ESTIMASI DAMPAK PERUBAHAN IKLIM TERHADAP KERAWANAN BANJIR LAHAR DI MAGELANG, JAWA TENGAH
}

\author{
Suprapto Dibyosaputro, Ahmad Cahyadi, Henky Nugraha, Slamet Suprayogi \\ Departemen Geografi Lingkungan Fakultas Geografi Universitas Gadjah Mada Yogyakarta \\ Email: supraptod@ugm.ac.id, ahmadcahyadi@geo.ugm.ac.id
}

\begin{abstract}
ABSTRAK
Perubahan iklim yang terjadi pada masa sekarang ini dirasakan terlalu cepat dibandingkan dengan perubahan yang iklim masa lampau yang telah dialami oleh Bumi. Hal ini dikhawatirkan akan menyebabkan perubahan yang drastis khususnya terkait dengan bencana yang dikontrol oleh aspek klimatologis. Penelitian ini bertujuan untuk mengestimasi dampak perubahan iklim terhadap kerawanan banjir lahar di Kabupaten Magelang yang sangat terkait dengan karakteristik hujan. Kajian ini membatasi pada kecenderungan perubahan hujan tahunan dan jumlah kejadian hujan ekstrem pada periode tahun eksisting, tahun 2020-an, 2050-an dan periode tahun 2080-an. Analisis dilakukan dengan skenario pemodelan Iklim HadCM3 dengan skenario emisi B2 sebagai skenario emisi dasar. Hasil kajian menunjukkan tiga dari empat stasiun amatan menunjukkan kecenderungan hujan yang semakin bertambah sampai dengan tahun 2100. Selain itu, jumlah kejadian hujan ekstrem di semua stasiun hujan amatan memiliki kecenderungan semakin bertambah. Hal ini berarti bahwa kerawanan banjir lahar di masa mendatang di Kabupaten Magelang cenderung mengalami peningkatan.
\end{abstract}

Kata Kunci: Banjir Lahar, Kerawanan, Magelang, Merapi

\section{PENDAHULUAN}

\section{Latar Belakang}

Gunungapi oleh Bronto (2006) diartikan sebagai suatu daerah di permukaan Bumi yang memiliki kawah sebagai tempat keluarnya magma yang berupa batuan pijar dan atau gas dari dalam Bumi yang kemudian menyebabkan terjadinya penumpukkan material di sekitar kawah sehingga membentuk topografi bukit atau gunung. Pengertian serupa diungkapkan oleh Schieferdecker (1959) yang menjelaskan bahwa gunungapi adalah sebuah tempat di permukaan Bumi di mana magma dari dalam Bumi keluar atau sudah keluar pada masa lampau, biasanya membentuk suatu gunung, kurang lebih berbentuk kerucut yang mempunyai kawah di puncaknya. Meskipun demikian, banyak dari peneliti menyebutkan bahwa syarat disebut sebagai gunungapi hanyalah apabila suatu tempat dipermukaan Bumi menjadi tempat keluarnya magma, hal ini mengingat banyak pula tempat dipermukaan Bumi yang merupakan tempat keluarnya magma namun tidak membentuk topografi bukit atau gunung. Pengertian ini misalnya disampaikan oleh Mulyaningsih (2015).

Thouret (1999) mengungkapkan bahwa Gunungapi merupakan suatu bentuklahan yang secara spesifik memiliki ancaman bencana. Ancaman bencana ini berdampingan dengan sumberdaya yang melimpah padanya, sehingga menyebabkan banyak manusia yang tinggal pada tubuh gunungapi (Chester et al., 2000). Beberapa bahaya gunungapi 
yang mungkin terjadi dan menyebabkan banyak kerugian di antaranya adalah jatuahn piroklastik, jatuhan awan panas, hujan abu, banjir lahar dan aliran lava (Bronto, 2001).

Gunungapi Merapi merupakan salah satu gunungapi yang paling aktif di dunia. Keberadaannya di dalam busur gunungapi yang dipengaruhi zona subduksi menyebabkan Gunungapi Merapi memungkinkan menghasilkan magma dengan jenis basa, intermediet dan asam. Hal ini berarti bahwa Gunungapi Merapi mungkin saja memiliki karakteristik letusan mulai dari efusif sampai dengan eksplosif. Meskipun demikian, Voight et. al. (2000) menyebutkan bahwa karakteristik umum dari letusan Gunungapi Merapi adalah berupa jatuhan awan panas. Selain itu, bahaya lain yang sering menyebabkan banyak korban jiwa di Gunungapi Merapi adalah banjir lahar (Lavigne et. al., 2000). Bahkan seringkali banjir lahar lebih merusak dan menghancurkan dibandingkan dengan aliran piroklastik pada beberapa kondisi, misalnya karena aliran lahar bergerak lebih jauh dibandingkan dengan aliran piroklastik (Wood dan Soulard, 2009; Gomez et al, 2009).

Erupsi Gunungapi Merapi selama ini memiliki indeks ekplosifitas yang beragam (Gambar 1). Seringkali letusan memiliki volcanic explosivity index (VEI) yang tinggi seperti tahun 2010. Hal ini biasanya juga diikuti dengan semakin banyaknya material yang dihasilkan. Hal ini kemudian akan berpengaruh terhadap sumber material yang dilontarkan sebagai jatuhan piroklastik dan hujan abu, material awan panas atau dapat pula menyebabkan semakin banyaknya material yang menumpuk di bagian puncak gunungapi sehingga material pembentuk aliran lahar akan semakin banyak.

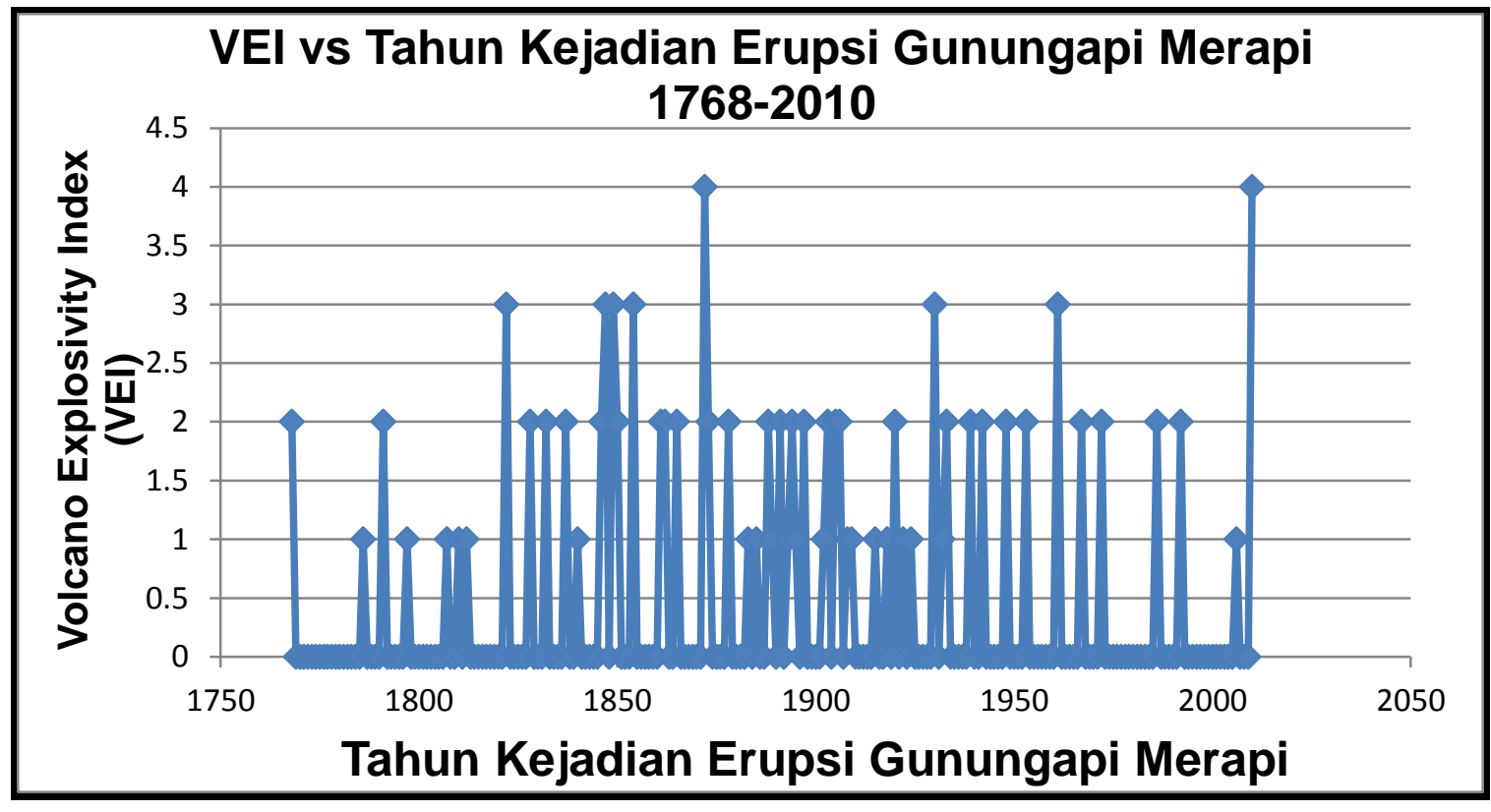

Gambar 1. Grafik skala VEI erupsi Gunungapi Merapi tahun 1768 - 2010

(Voight, dkk. 2000 dan Brotopuspito, dkk. 2011)

Kabupaten Magelang adalah salah satu Kabupaten yang berada di bagian barat Gunungapi Merapi. Kabupaten Magelang adalah satu dari dua kabupaten (selain Kabupaten Sleman) yang selalu terdampak cukup parah ketika terjadi erupsi Gunungapi Merapi. Tabel 1 menunjukkan bahwa pasca erupsi Gunungapi Merapi pada tahun 2010, Kabupaten magelang adalah Kabupaten yang mengalami banjir lahar merusak paling banyak dibandingkan dengan kabupaten lain yang memiliki wilayah di Gunungapi Merapi. 
Tabel 1. Jumlah Kejadian Banjir Lahar Merusak Pasca Erupsi Gunungapi Merapi Tahun 2010

\begin{tabular}{|l|r|r|}
\hline \multicolumn{1}{|c|}{ Kabupaten } & Jumlah Kejadian & \multicolumn{2}{c|}{ Persen Kejadian } \\
\hline Sleman & 33 & 32.67 \\
\hline Magelang & 64 & 63.37 \\
\hline Boyolali & 0 & 0.00 \\
\hline Klaten & 4 & 3.96 \\
\hline Jumlah & 101 & 100.00 \\
\hline
\end{tabular}

Sumber: Brontopuspito dkk. (2011)

Mekanisme kejadian banjir lahar di Gunungapi oleh Lavigne et al. (2006) dibagi tiga mekanisme pembentukkan lahar. Pertama lahar syn-eruptive, yaitu lahar yang terbentuk pada saat letusan. Kedua, lahar post-eruptive, yaitu lahar yang terjadi pasca letusan. Ketiga lahar non-eruptive, yaitu lahar yang terbentuk dengan tidak diawali adanya letusan dan biasanya terjadi pada Gunungapi yang tidak aktif / dorman. Mekanisme yang pertama dan kedua merupakan mekanisme yang umum terjadi di Gunungapi Merapi (Lavigne et al., 2000) Hal ini berarti bahwa hujan memiliki peranan yang sangat penting dalam pembentukkan aliran lahar yang terdapat di Gunungapi Merapi.

Kekhawatiran kenaikan ancaman gunungapi saat ini menjadi perhatian banyak peneliti, khususnya terkait dengan fenomena perubahan iklim. Meskipun sebenarnya dalam sejarah Bumi diketahui bahwa Bumi telah mengalami berbagai perubahan iklim yang ekstrem (Goudie, 1994; Hugget, 1991), kekhawatiran ini muncul karena perubahan unsurunsur iklim yang terjadi saat ini berlangsung dengan lebih cepat dari sebelumnya (Dragoni dan Sukhija, 2008). Perubahan yang cepat ini oleh Huntington (2006) diperkirakan disebabkan oleh adanya pengaruh emisi gas rumah kaca dari pembakaran bahan bakar fosil yang marak dilakukan sejak revolusi indutri. Perubahan iklim menyebabkan banyak perubahan terkait dengan intensitas curah hujan, kejadian hujan ekstrem, terlambatnya musim kemarau dan musim penghujan, berkurang atau bertambahnya curah hujan serta peningkatan suhu rata-rata udara (IPCC, 2007; Ducci dan Tranfaglia, 2008; Polemio dan Casarano, 2008). Hal inilah yang nantinya dapat menyebabkan terjadinya perubahan tingkat kerawanan suatu wilayah terhadap bencana volkanik, terutama banjir lahar.

Penelitian ini bertujuan untuk melakukan analisis dampak perubahan iklim terhadap karakteristik curah hujan dan kemungkinan dampaknya terhadap kerawanan banjir lahar di Magelang, Jawa Tengah. Hasil kajian ini diharapkan dapat menjadi bagian pertimbangan dalam penyusunan rencana penanggulangan bencana gunungapi khususnya di Gunungapi Merapi di masa mendatang dengan memasukkan analisis dampak perubahan iklim.

\section{METODE}

\section{Alat dan Bahan Penelitian}

Alat dan bahan yang digunakan dalam penelitian ini meliputi:

1. Data hujan Stasiun Hujan Kintelan, Dukun, Babadan dan Borobudur Tahun 19712001;

2. Data lokasi Stasiun Hujan Kintelan, Dukun, Babadan dan Borobudur; 
Suprapto Dibyosaputro, Ahmad Cahyadi, Henky Nugraha, Slamet Suprayogi; Estimasi Dampak Perubahan Iklim Terhadap Kerawanan Banjir Lahar di Magelang, Jawa Tengah

3. Data General Circulation Model tahun 1971-2100 di lokasi kajian dengan skenario perubahan iklim HadCM3 dengan skenario emisi B2 yang diperoleh dari http://www.cccsn.ca ;

4. Data NCEP/NCAR Reanalysis Tahun 1971-2001 skenario emisi B2 yang diperoleh dari http://www.ncep.noaa.gov .

\section{Metode Analisis Data}

Data hujan yang digunakan dalam penelitian ini adalah data hujan harian yang tercatat pada empat stasiun hujan di Kabupaten Magelang (lereng barat Gunungapi Merapi), yakni stasiun hujan Borobudur, Babadan, Dukun dan Kintelan. Data Hujan yang digunakan adalah data hujan tahun 1971 sampai dengan 2001. Hal ini sesuai dengan data dasar yang digunakan dalam membangun data General Circulation Model (GCM) dan data NCEP/NCAR Reanalysis. Data hujan yang diperoleh kemudian dianalisis dengan pengisian data hujan yang kosong, uji korelasi dan uji konsitensi.

Hasil analisis data hujan eksisting kemudian digunakan untuk menyusun pemodelan iklim dengan menggunakan skenario perubahan iklim HadCM3 yang dikembangkan oleh United Kingdom Hadley Center. Skenario emisi yang digunakan dalam penelitian ini adalah skenario emisi B2 yang merupakan skenario emisi dasar. Data yang diperoleh dari data GCM adalah data yang mewakili grid sebesar $2.5^{\circ} \times 3.75^{\circ}$. Oleh karena itu kemudian dilakukan analisis downscaling dengan membandingkan data GCM dengan data masingmasing stasiun. Analisis ini kemudian menghasilkan data hujan harian pada masing-masing stasiun.

Analisis yang dilakukan dalam penelitian ini meliputi analisis kecenderungan curah hujan tahunan dan kecenderungan kejadian hujan ekstrem. keduanya di analisis pada kondisi eksisting, periode iklim 2020an, periode iklim 2050an dan periode iklim 2080an. Curah hujan tahunan dihitung dengan menjumlah curah hujan harian selama setrahun, kemudian dihitung reratanya pada periode iklim yang sama. Kejadian hujan ekstrem yang dianalisis pada penelitian ini adalah kejadian hujan dengan intensitas lebih dari $100 \mathrm{~mm} / \mathrm{hari}$.

\section{HASIL DAN PEMBAHASAN}

Hasil analisis yang telah dilakukan menunjukan tiga stasiun hujan di Kabupaten Magelang memiliki kecenderungan hujan tahunan yang semakin bertambah (Gambar 2). Ketiga stasiun hujan yang dimaksud adalah stasiun hujan Babadan, Dukun, dan Borobudur, sedangkan satu stasiun observasi memiliki kecenderungan penurunan curah hujan tahunan yaitu stasiun hujan Kintelan. Meskipun demikian, masing-masing stasiun pada periode sebenarnya memiliki kecenderungan yang terbalik dari pola kecenderungan umum dari kondisi eksisting sampai dengan tahun 2100. Stasiun hujan Babadan, Borobudur dan Dukun misalnya memiliki kecenderungan hujan tahunan yang menurun pada periode iklim eksisting sampai periode iklim tahun 2020an (tahun 2011 - 2040), sedangkan pada periode berikutnya yakni periode iklim 2020an ke 2050an (2041-2070) dan periode iklim 2050an ke 2080an (tahun 2071 - 2100) mengalami kenaikan curah hujan tahunan yang cukup tinggi, yakni sekitar $30 \%$ dari periode sebelumnya. Hal yang berbeda ditunjukkan pada stasiun hujan Kintelan yang memiliki kecenderungan naik pada periode iklim eksisting ke periode iklim 2020an, dan mengalami penurunan pada periode iklim 2020an - 2050an dan pada periode iklim 2050an ke periode iklim 2070an. 
Hasil analisis terkait dengan kecenderungan hujan tahunan pada paragraph sebelumnya menunjukkan bahwa pada skala lokal masing-masing wilayah mengalami dampak perubahan iklim dengan kondisi yang berbeda-beda. Hal ini dapat terjadi akibat banyak faktor lokal seperti ketinggian tempat, arah hadap lereng, kedekatan dengan sumber air yang menjadi bahan baku penguapan, keberadaan gerakan orografis, serta kondisi morfologi wilayahnya. Meskipun demikian, dari hasil analisis yang telah dilakukan, maka diketahui bahwa secara garis besar kecenderungan curah hujan tahunan di Kabupaten Magelang akan semakin tinggi.

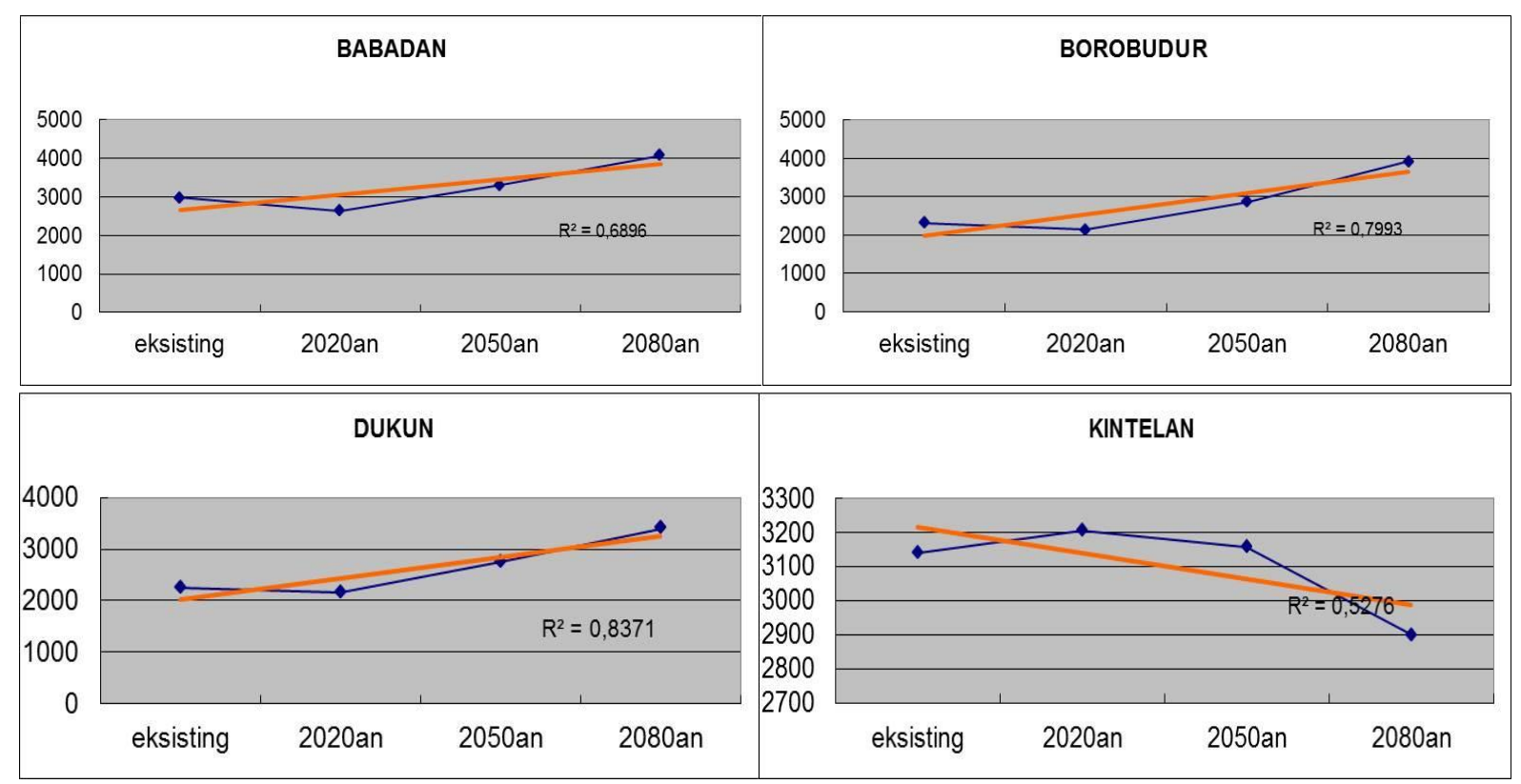

Gambar 2. Kecenderungan Hujan Tahunan pada Beberapa Stasiun Hujan di Kabupaten Magelang

Kenaikan curah hujan tahunan secara positif akan meningkatkan ketersediaan sumberdaya air apabila dapat dikelola. Material porus material piroklastik akan menyebankan banyak air yang meresap menjadi airtanah yang sebagiannya kemudian muncul sebagai mataair dan mensuplai aliran sungai pada musim kemarau. Namun demikian, apabila hujan terjadi berturut-turut dengan intensitas yang tinggi, maka kemungkinan terjadinya banjir lahar akan semakin besar. Selain itu, hujan dengan intensitas tinggi juga akan menyebabkan lebih banyak kejadian luapan banjir lahar melampaui tanggul sungai, sehingga dampak yang ditimbulkan akan menjadi lebih besar.

Analisis kejadian hujan ekstrem pada hasil pemodelan iklim skenario HadCM3 dengan skenario emisi B2 menunjukkan bahwa semua stasiun hujan memiliki kecenderungan kejadian hujan ekstrem yang semakin tinggi (Gambar 3). Hujan ekstrem yang terjadi paling banyak adalah dengan intensitas antara $100 \mathrm{~mm} / \mathrm{hari}$ sampai dengan $150 \mathrm{~mm} /$ hari. Kejadian hujan ekstrem paling banyak terjadi pada stasiun Babadan, sedangkan paling rendah pada stasiun hujan Dukun. Kejadian hujan ekstrem di stasiun Babadan meningkat dari 22 kejadian pada periode iklim 53 kejadian pada periode iklim tahun 2050an dan meningkat lagi menjadi 81 kejadian pada poeriode iklim tahun 2080an.

Hasil kajian yang telah dilakukan menunjukkan bahwa kerawanan banjir lahar di masa mendatang di Kabupaten Magelang akan semakin besar. Tentunya hal ini juga terkait 
dengan kejadian erupsi Gunungapi Merapi di masa mendatang. Kejadian hujan ekstrem yang terjadi pada periode di mana letusan gunungapi sudah lama tidak terjadi akan memiliki dampak yang berbeda dengan kondisi saat hujan ekstrem terjadi pada saat erupsi baru saja terjadi. Material yang belum padu, serta kemampuan material baru dalam meresapkan air yang berbeda jauh dengan material lama kana menyebabkan terjadinya bidang gelincir pada batas antara keduanya. Hal ini kemudian memicu terjadinya banjir lahar.

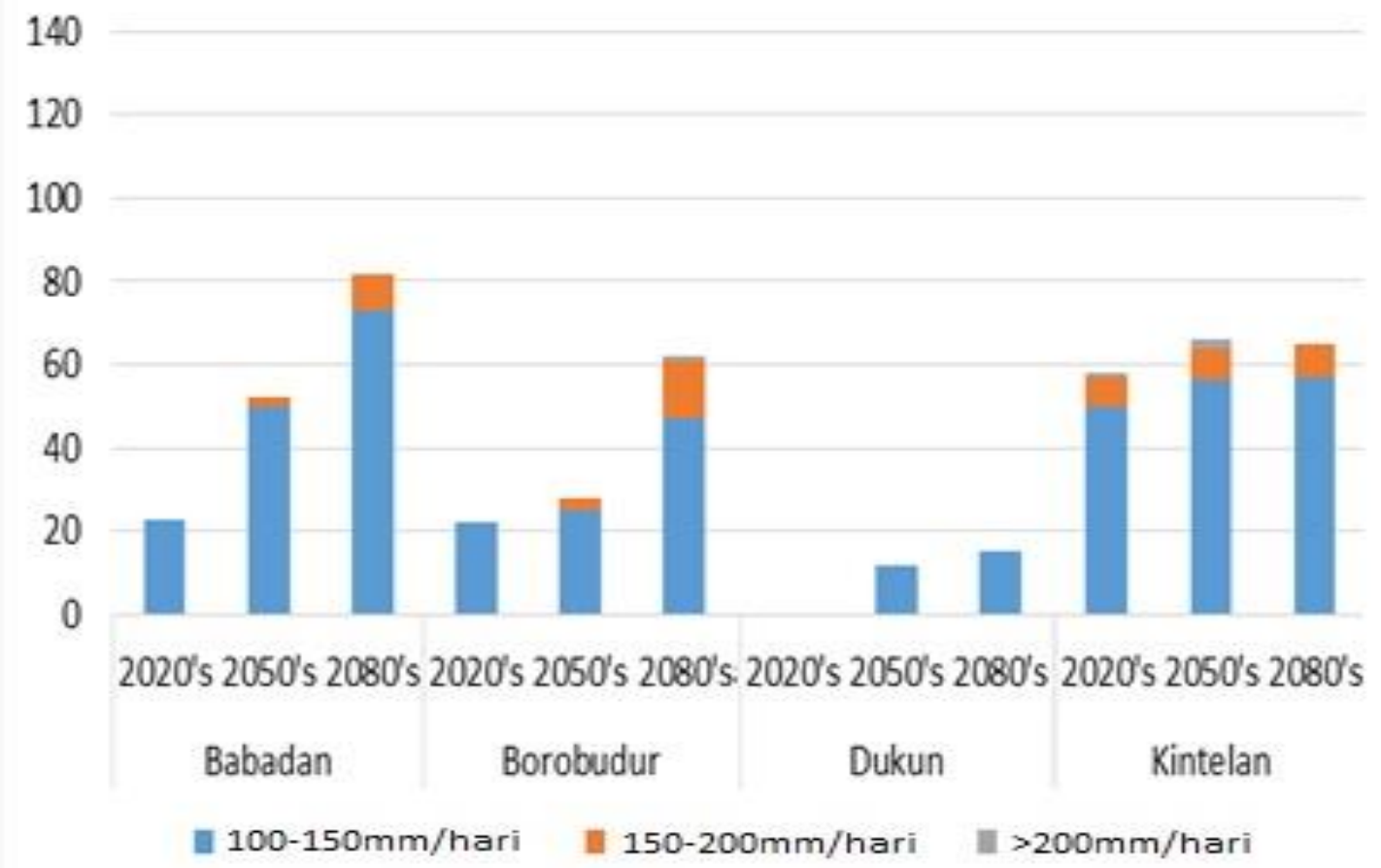

Gambar 3. Kecenderungan Kejadian Hujan Ektrem di Kabupaten Magelang Berdasarkan pada Hasil Pemodelan Iklim

Kejadian hujan ekstrem yang semakin sering terjadi akan menyebabkan material piroklastik yang baru menjadi sangat jenuh. Hal ini kemudian menyebankan semakin besarnya massa dari material dan semakin kecilnya gaya gesekan antara material piroklastik yang baru dengan material piroklastik yang lama. Hal inilah yang kemudian menyebabkan banjir lahar.

\section{KESIMPULAN}

Berdasarkan hasil analisis analisis yang telah dilakukan, maka diketahui bahwa tiga dari empat stasiun observasi menunjukkan kecenderungan hujan tahunan yang semakin bertambah sampai dengan tahun 2100. Hal lain yang dapat diamati adalah bahwa jumlah kejadian hujan ekstrem di semua stasiun hujan observasi di Kabupaten Magelang memiliki kecenderungan semakin bertambah. Kondisi demikian menunjukkan bahwa kerawanan banjir lahar di masa mendatang di Kabupaten Magelang cenderung mengalami peningkatan. 


\section{PENGHARGAAN (acknowledgement)}

Penelitian ini merupakan bagian dari hibah Penelitian Unggulan Perguruan Tinggi (PUPT) Kementerian Riset, Teknologi dan Pendidikan Tinggi (Kemenristekdikti) tahun 2016 yang berjudul "Integrasi Kajian Kebencanaan untuk Mendukung Perencanaan Pengembangan Wilayah dan Peningkatan Kapasitas Masyarakat Pada Kawasan Rawan Bencana Gunungapi” dengan nomor kontrak 679/UN1-P.III/LT/DIT-LIT/2016.

\section{REFERENSI}

Bronto, S. 2006. Fasies Gunung Api dan aplikasinya. Jurnal Geologi Indnesia, vol. 2(1). 5971.

Bronto, S. 2001. Penilaian Potensi Bahaya Gunung Galunggung Kabupaten Tasikmalaya, Jawa Barat. Alami: Jurnal, Air,Lahan, Lingkungan, dan Mitigasi Bencana, vol. 6. 113. Jakarta:BPPTMulyaningsih. 2015. Volkanologi. Yogyakarta: Ombak.

Brotopuspito, K.S.; Suratman; Pramumijoyo, S.; Hadmoko, D.S.; Harijoko, A. dan Suyanto, W. 2011. Kajian Multi-Bahaya, Kerentanan, Risiko, Desain Tata Ruang Kawasan Rawan Bencana Merapi dan Implementasinya dalam Peningkatan Kapasitas dan Kesiapsiagaan Masyarakat Terhadap Bahaya Gunungapi. Laporan Penelitian. Hibah Penelitian Strategis Nasional Universitas Gadjah Mada.

Dragoni, W. dan Sukhija, B.S. 2008. Climate Change and Groundwater: A Short Review. dalam Dragoni, W. dan Sukhija, B.S. 2008. Climate Change and Groundwater. London: Geological Society.

Ducci, D. dan Tranfaglia, G. 2008. Effects of Climate Change on Groundwater Resources in Campania (Southern Italy). dalam Dragoni, W. dan Sukhija, B.S. 2008. Climate Change and Groundwater. London: Geological Society.

Goudie, A. 1994. The Human Impact on the Environment. Cambrigde: The MIT Press.

Huggett, R.J. 1991. Climate, Earth Proceses and Earth History.Springer Verlag.

Huntington, T.G. 2006. Evidence for Intensification of the Global Water Cycle: Review and Syntesis. Journal of Hydrology, 319: 83-95.

IPCC. 2007. The Physical Science Basis - Summary for Policymakers. Contribution of WGI to The Fourth Assessment Report of The Intergovernmental Panel on Climate Change. Diakses dari http://www.ipcc.ch/ipccreport/ar4-wgl.htm.

Polemio, M dan Casarano, D. 2008. Climate Change, Drought and Groundwater Availability in Southern Italy. dalam Dragoni, W. dan Sukhija, B.S. 2008. Climate Change and Groundwater. London: Geological Society.

Schieferdecker, A.A.G. (Ed.). 1959. Geological Nomenclature. Royal Geol. And Minings Soc. Of the Netherlands, J. Noorduijn en Zoon N.V., Gorinchem, 523h. 